Г. В. Демура

\title{
МОВНІ ЗАСОБИ ІДЕОЛОГІЗАЦІЇ ОБРАЗУ ЧОЛОВІКА В УКРАЇНСЬКІЙ РАДЯНСЬКІЙ ПРЕСІ 20-40 РР. ХХ СТ.
}

\footnotetext{
Демура Г. В. Мовні засоби ідеологізації образу чоловіка в українській радянській пресі 20-30 pp. XX ст.

Стаття містить аналіз вербальних особливостей формування гендерної політики в українських засобах масової інформації 20-40 pp. XX ст. з урахуванням ідеологічних канонів, характерних для преси зазначеного періоду.

Ключові слова: маскулінне, гендерна політика, засоби масової інформації, дискурс, радянська ідеологія, мовні засоби, тоталітарний режим.
} 
Демура Г. В. Языковые средства идеологизации образа мужчины в украинской советской прессе 20-40 гг. ХX в.

В статье анализируются вербальные особенности формирования гендерной политики в украинских средствах массовой информации 20-40-гг. ХХ ст. с учетом идеологических канонов и классового подхода, характерных для прессы указанного периода.

Ключевые слова: маскулинное, гендерная политика, средства массовой информации, дискурс, советская идеология, языковые средства, тоталитарный режим.

Demura G. V. Language Stylistics of ideologizing Means of man's Image Actualization in the Ukrainian Soviet press 20-40s in the XX century.

Verbal peculiarities of forming gender policy in Ukrainian mass-media in 20-40s of $20^{\text {th }}$ century are analyzed taking into account ideologic canons and class approach which are typical for the press of the mentioned period.

Key words: masculinity, gender policy, mass-media, discourse, soviet ideology, means of language, totalitarian society.

Мова $\epsilon$ важливим засобом впливу на членів соціуму. Те, як мова зображує жінок та чоловіків, має неабиякий вплив на їхню роль та ставлення до них у суспільстві. Важливу роль у цьому відіграють засоби масової інформації (3МI), здатні в найкоротший термін донести інформацію до різних верств населення в найвіддаленіших куточках країни. Мова аналізованої нами преси належить до публіцистичного й тоталітарного дискурсів. Цей синтез дискурсів підпорядковується панівній ідеології тоталітарної держави, особливістю якої $\epsilon$ використання спеціально створеної мови - новомови.

Г. Яворська вважає, що «мова тоталітаризму з певного погляду може розглядатися як своєрідний експеримент, у якому до краю доведено можливості маніпулювання мовою 3 метою іiі використання як засобу жорсткого соціального контролю» [10, с. 218]. «Саме за допомогою мови, вважає дослідниця, - створюється міфічний образ дійсності, 3 прототипним міфом про боротьбу сил добра із силами зла і відповідним чітким поділом світу на «своїх» та «чужих» < .. > Крім того, як з'ясувалося 3 лінгвістичних досліджень, тоталітарна мова не обмежується політичним дискурсом. Ї̈і не можна звести до мови пропаганди» [10, с.218].

Також характерною рисою тоталітарного суспільства $є$ «людина маси», якою легше маніпулювати й керувати. Метою радянської влади було втілення ідей рівності ста́тей у «новому» суспільстві. Гендерні проблеми розглядалися виключно з погляду тодішньої офіційної ідеології. Гендерна рівність, проголошена в ці роки, залишалася на папері та на законодавчому рівні, оскільки тоталітарна культура була виразно маскулінізованою.

Об'єктом здійснення гендерної політики були не просто чоловіки й жінки, а представники й представниці певних соціальних груп. Якщо гендерологи досліджували переважно відмінності «чоловічого» та «жіночого» мовлення, то ми проаналізували, як за допомогою мови створювалися чи спотворювалися образи чоловіків та жінок.

За допомогою мови преси нівелювалося «фемінне» і «маскулінне». Уважаємо, що тоталітарному режимові, який панував у СРСР, був (C) Г. В. Демура, 2011. 
притаманний «страх статі». За допомогою нівелювання ґендерних особливостей чоловіків i жінок, влада намагалася створити «нову» суспільну одиницю - радянську людину, яка мала чітко слідувати вимогам і настановам партії. До формування цієї «нової» людини були залучені держава, потужна пропагандистська машина i, насамперед, засоби масової інформації, які, у свою чергу, пропагували ті риси, якими повинна була володіти людина комуністичної формації.

Створення «нових» радянських ідеальних людей, лояльних до режиму, відбувалося за допомогою мовних засобів - відповідного номінування чоловіків і жінок за їхніми функціями, належністю до певних класів, уживання різної оцінної лексики, означень. Цю динаміку можна простежити на прикладі змін лексико-семантичних груп у зазначений період.

Об'єктом нашого дослідження є мова газет «Більшовик», «Радянська Донеччина», «Україна» та журналів «Комунарка України», «Радянська жінка», «Робітниця». Предметом аналізу стала лексико-семантична група «чоловік» у мові названих видань.

На сторінках аналізованих видань 20-х р. номінування чоловіків найчастіше здійснювалося за допомогою лексем робітник, селянин. Розглянемо номінацію чоловіка як представника найпередовішого, згідно 3 ідеологічними канонами того часу, робітничого класу. Наприклад: Геть безправство робітницьь й робітників, будемо разом з робітниками боротися за перемогу світового комунізму! (Б, 1923, №53); В праці господарі не відріжняють робітників від робітниць - їх примушують тягати вагу так само, як і робітників, працювати на полі (орати, боронити і т. інш.) (КУ, 1922, №13).

У наступних прикладах виразно підкреслюється тенденція преси 30-х р., де автори статей акцентують увагу на ударній праці. Це зумовлено тим, що в цей час з'являється новий ціннісний орієнтир, нова реалія дійсності - стахановський рух. Узірцем для усіх робітників став О. Стаханов, який завдяки своїй ударній праці зробився героєм-символом радянської людини комуністичної формації. На нашу думку, у більшості робітників змінилося саме ставлення до роботи - усі прагнули не лише виконати, а й перевиконати план. Тому і називання передових робітників і робітниць було відповідним: Кращі стахановці 4 цзеху швейной фабрики ім. Горького тт. Григор'єв і Привульський за минулий місяцьь заробили понад 1000 крб. кожний (Б, 1938, №15); Стахановець 1 пошивочного чзеху 1 взуттєвої фабрики т. Макаровський майже цілком присвячує свою промову на мітингу визначній подї - рекорду радянських льотчиків Коккінакі та Бряндинського (Б, 1938, №150).

У пресі післявоєнного періоду чоловіки прагнули перевиконати норми, оскільки країна була розорена війною, тому будь-які згадування про перевищення плану знаходили широкий резонанс у публікаціях: Приклад в цзьому показав колектив шахти «Кочегарка». Підрахувавши свої 
можливості, гірники вирішили до 30 листопада закінчити виконання річного плану вуглевидобутку. Передові вибійники цієї шахти т.Грушко, Сергеєв, Шевельов, Шматько і інші зобов 'язались виконати по три річних норми (РД, 1946, №131); Виконавщи достроково піврічний план, колектив металургів «Азовсталі» зобов'язалися витопити ще 14.000 тонн понадпланового чавуну i 13.500 тонн сталі. Доменники свою обіиянку виконали (РД, 1946, №131); Макіївська доменна піч №1 - че двадията піч, введена до ладу після визволення радянської землі від німецьких загарбників. Сталетопники перевищили зобов'язання на 500 тонн сталі (РД, 1946, №131); Сьогодні заспівувач соціалістичного змагання врубмашиністів Герасим Запорожець показав нові зразки чудової роботи, уміння в будь-яких умовах домагатися високої продуктивності врубмашини (РД, 1946, №227).

Показово, що у проаналізованих нами газетних матеріалах 20-х рр. практично відсутні, за незначними винятками, згадки про чоловіків як представників інтелігенції. Це зумовлено тим, що, з погляу диктатури пролетаріату, інтелігенція вважалася думаючою, відповідно ненадійною частиною населення: Ця інтелігенція то заповнювала білогвардійські штаби, то тихо сичала і таємно снувала нитки своӥх змов проти пролетаріату. В Жовтні почалася справжня трагедія інтелігенції. Так звана «свободолюбива», «демократична» інтелігенція почала рішучий наступ на пролетаріат (Б, 1924, №76); Кожен робітник, кожен селянин, кожен червоноарміец, ще віддав свої сили, здоровля та навіть життя, був певен того, що сам він, коли втратить здоровля, або його родина будуть забезпечені державою (КУ, 1923, №2-3). В останньому прикладі взагалі відсутні лексеми на позначення людей інтелектуальної праці, свідоме неназивання інтелігентних людей, в особі яких партія бачила «ворогів» народу. Натомість у пресі післявоєнного періоду з'явилася нова реалія «радянська інтелігенція» - образ «нової» комуністичної людини, політично та ідеологічно свідомої: Радянський інтелігент мусить бути ленінцем, сталінцем, мусить знати закони розвитку суспільства і вміти ними користуватись у творчій роботі (ПЖ, 1947, №3). Структура і зміст вищезазначених лексем постійно перебувають під впливом засобів оцінності. Про таку оцінність говорить М. Гловінський, зазначаючи в есеї «Новомова», що «часто оцінки, які призводять до дихотомічних поділів, стають важливішими від значень» [4, с. 159]. Так, якщо йдеться про радянську інтелігенцію, то ця ознака $\epsilon$ апріорі позитивною, оскільки смислове та оцінне наповнення слова «інтелігент» залежить від означення «радянський» та згадування в одному контексті номінувань, похідних від Леніна та Сталіна. Протилежне явище спостерігаємо, коли лексема «інтелігент» уводиться до контексту поряд із ідеологічно «ворожими» поняттями, як то «білогвардійський штаб» чи «демократичний», тому негативна оцінка автоматично на неї поширюється. 
Ще один приклад подібної дихотомії зустрічаємо у статті, у якій описується життя відомого вченого Ївана Мічуріна: $B$ провінціальному містечку царської Росї - Козлові, серед неуків, тупиць, мракобісів, обивателів, живе великий російський садовод, геніальний вчений, людина, щуо відкрила нові шляхи в науці - Іван Володимирович Мічурін < .. > На широкий творчий шлях вивела і. В. Мічуріна Велика Жовтнева сочіалістична револючія, яку старий вчений сприйняв $з$ юнацьким ентузіазмом, палко $і$ захоплено <...> Звитяжним було життя геніального сина російського народу - прапороносця передової радянської науки I. B. Мічуріна (РЖ, 1949, №2). Ефект дихотомії створюється за допомогою нагнітання в одному контексті лексем з різко негативною оцінкою (як то «неуки», «тупиці», «мракобіси»), які характеризують жителів царської Росії (тобто «чуже»), та мовних одиниць $з$ позитивним забарвленням для зображення самого вченого (тобто «своє»).

В аналізованих статтях меншою мірою розглянуто «чоловіче» питання: маскулінне мислилося і висвітлювалося однобічно: чоловік - це воїн, працівник (бажано, щоб передовий), свідомий партієць: На зеленому плацу зібралися червоноармійці, командири і політпрацівники частини, де комісаром тов. Філіпов (Б, 1938, №149). Також у публікаціях зазначеного періоду героїзувався образ чоловіка шляхом уведення відповідних означень. Поряд із героями-стахановцями оспівувалися й інші, не менш героїчні постаті: Славним синам нашої великої батьківщини, сталінським вихованцям, безстрашним дослідникам Арктики - палкий більшовицький привіт! (Б, 1938, №41).

Однією з головних ролей для чоловіка була роль захисника держави, жінки, а неодмінним місцем такого змужніння залишалася армія, яка на сторінках преси активно героїзувалася. Таку героїзацію чоловіків можна пояснити особливістю стилю тоталітарного дискурсу. Зокрема Б. Потятиник вважає, що «стиль тоталітарної пропаганди в СРСР 20-30 рр. можна умовно позначити як «героїчний» - 3 огляду на домінуючу «гостроту» висловлювань, які мали передавати напругу життя» [7, с. 96]. Наприклад, Наша Червона армія є знаряддя зміинення влади робітників $i$ селян, знаряддя зміџнення диктатури пролетаріяту, знаряддя визволення робітників і селян від кормиги поміщчиків $i$ капіталістів. Наша армія $\epsilon$ армія визволення трудящих (КУ, 1933, №3). О. Забужко вважає, що «у тоталітарному супільстві, байдуже, фашистському чи комуністичному, вся ідеологічно санкціонована «стать» скупчується в мілітарних інститутах - i в радянському, i в нацистському етичному кодексі «справжнього мужчину» 3 хлопця робить армія - HE жінка. <..> Тоталітаризм i гомосексуалізм невіддільні від себе (за Т. Адорно - Г.Д.) <..> а в буквальному сенсі статеві органи влади - цього Абсолюту Чоловічости. Строго кажучи, тоталітаризм не тим «деміфологізує» жінку, що міфологізує Вождя - «батька народів» і водночас божисту персоніфікацію маскулінности» [5, с. 156-158]. 
У пресі післявоєнного періоду прикладом такого «змужніння» стала друга світова війна, образи чоловіків героїзувалися за допомогою добору відповідної лексики: М. І. Козлов - один із найстаріших $i$ досвідчених полярних льотчиків. Учасник історичного польоту на Північний полюс, М. I. Козлов з перших днів війни бомбив військові об'єкти противника. Полковника М. I. Козлова нагороджено 6 орденами (У, 1945, №1); В. А. Томашевський став комісаром, потім начальником загону в партизанському з'єднанні українського вчителя, Героя Радянського Союзу Антона Одухи. Він бився $з$ ворогом у Галичині та в Білорусї, брав $i$ відстоював міста, винищував німецькі гарнізони й читав по німецьких комендатурах оголомення про те, яку нагороду обіияно за його власну голову (У, 1945, №1).

Як уже зазначалося раніше, радянський тоталітаризм був у своїй сутності чоловічою культурою. «Офіційний тілесний канон радянського мистецтва 30 -х років XX ст. характеризується надміром оголеної чоловічої плоті - паради з участю напівоголених гімнастів, численні скульптури спортсменів, розквіт спортивної фотографії. Щоправда, на відміну від нацистського, у радянському мистецтві геніталії завжди прикриті, його тілесний еталон більше нагадує унісекс. Але цей «унісекс» як в естетиці, так і в педагогіці, був сильно маскулінізований» [2]. Ця особливість радянської тоталітарної культури простежується і в пресі аналізованого періоду. Наприклад, Найяскравіший момент в параді - iдуть фізкультурники-бійці Червоної Армї̈. Силу, мужність, здоров'я і красу молодих патріотів радянської землі, щасливих вихованців сталінської епохи - показав вчорашній парад в якому взяли участь 24.000 фізкультурників (Б, 1938, №154).

Часто на сторінках преси протиставлялися образи чоловіків: несвідомого, що не хоче відпускати свою дружину на збори, і свідомого робітника, який їй у цьому всіляко допомагає. Наприклад, Одна з перешкод [для жіночого навчання - Г. Д.] - чоловіки «гризуть», щюб жінки дома сиділи, а не вчитися ходили. Инший сам учиться, а не хоче щоб і жінка 3 темряви вирвалася. Тим приємніше вражіння справив на учаснищь конферениії ось який випадок: Підчас роботи конференції стукає хтось у двері. Відчинили - робітник: - Тут десь моя дружина з маленям. Воно розплакатися може, так я хочу дитину забрати, щоб досиділа вона спокійно. Такий чоловік - справжня дружина свойй жінці (КУ, 1924, №18). В ілюстрації спостерігаємо зміну ролей у родині, запропоновану партією до того часу, поки жінка не стане освіченою, свідомою робітницею. Тому чоловік ставав дружиною своїй жінці (дружині).

У пресі 20-40-х рр. практично відсутні слова і словосполуки на позначення чоловіка як батька, вихователя дітей. Наявні випадки такого номінування радше є винятками, що підтверджують цю тенденцію: $\mathrm{Ha} 8$ березня чоловіки залишалися дома з дітьми, а жінки, хатні невільниці, 
йшли на збори (Б, 1923, №53). У цьому прикладі простежується протиставлення лексем «дім» та «збори», які стають контекстуальними антонімами. Говорячи про маскулінне в тоталітарному суспільстві, О. Забужко вважає, що «будь-які форми соціального приниження завжди зачіпають мужчин куди глибше й безпосередніше, ніж жінок, - вже 3 тої простої причини, що для жінки праця й родина $є$ рівнобіжними <..> способами особистісної соціалізації, тимчасом як для чоловіка вони нерозривно взаємопов'язані: <..> якщо для жінки кухня й дитяча залишаються iі невід'ємним «резервним плацдармом» для відступу, то чоловікові відступати <..> «нема куди» [5, с.162-163].

У пресі аналізованого періоду авторами статей засуджувалися чоловіки-алкоголіки, які заважають своїм дружинам щасливо жити. Згадаймо, що саме в 20-30-х рр. партія пропагувала ідеал міцної, щасливої родини. Нерідко самі дружини таких чоловіків були авторками викривальних матеріалів: укладчиця загорток на фабриці «Червоний кондитер» Ткаченко скаржиться: - Мій чоловік п'яниця, все жсиття псує. Як нап'ється, так і лізе битись. Хоч би суд над ним влаштували в майстернях, де він працює. Таких чоловіків-п'яниць треба на показ <... Хіба такі чоловіки не злочинці. Їх треба, як злочинців, до в'язниці сажнати. Що він з мене зробив! Я тепер - людина хвора, нервова $і$ все через чоловіка-n’яницю (КУ, 1929, №7). Цікаво, що слова на позначення цієї чоловічої вади, набували синонімічних відношень. Так, між лексемами «чоловік-алкоголік» і «злочинець» можна поставити знак рівняння.

У наступному прикладі з виразною виховною метою проведено суд над алкоголіком-робітником, щоб довести, що алкоголь - зло, яке заважає чоловікам працювати, порушуючи таким чином їхню першочергову робочу функцію: У неділю 6 квітня в клубі «Нархарч» відбувся суд над алкоголіком, який виконали учні иколи Фабзавуча за допомогою санпросвітнього гуртка. Робітництво як на долоні побачило, яке зло приносить алкоголь. Не вадило-б побільше таких санпросвітніх судів, які розплющують робітництву очі (Б, 1924, №81).

Ще однією «чоловічою» проблемою, висвітлюваною у пресі зазначеного періоду, є картярство. Жінка у свою чергу має допомогти боротися з цією проблемою: «Очко»-лихо робімничої сім'ї. Викорінити його мусить допомогти й жсінка. Справа жсінвідділу на місияя організувати жінок для боротьби з картярством (КУ, 1928, №12).

До «чоловічих» проблем автори статей зараховують і лінощі, як ознаку багатовікової вищості над жінкою. А це аж ніяк не відповідало пропагованому більшовицькому ідеалові, основними складниками якого є: гендерна рівність, партійна свідомість робітників i робітниць, «нові» радянські люди без вад, такі собі роботи. Наприклад, Зараз жсінки чоловіків підтягують до свого виробничого рівня, часто беруть ввесь провід в свої руки і проводять дуже велику роботу, щзоб підвищити 
трудову свідомість чоловіків, викорінити з них вікову лінивість «святість вищцого полу» причиту їм попами (Р, 1932, №10).

Отже, чоловікові в державі пропонувалися ролі захисника, воїна, рідше, батька, вихователя дітей. Таким чином, партія наголошувала на першочерговій функції чоловіків - робочій. У свою чергу тоталітарна культура залишалася чоловічою, пропагуючи виразно маскулінізовану естетику - унісекс. У публікаціях зазначеного періоду аналізувалися «чоловічі» проблеми соціального характеру i практично повністю замовчувалися проблеми психо-фізіологічні.

Мова ЗМІ аналізованого періоду стала потужним засобом маніпулювання людьми. За допомогою активно вживаної (популярної) лексики партія пропагувала образи «нових» чоловіків, потрібних державі.

\section{Література}

1. Бацевич Ф. С. Нариси з комунікативної лінгвістики / Ф. С. Бацевич. - Львів : Вид. центр ЛНУ ім. І. Франка, 2003. -278 с.

2. Герінгтон К. Фалічна маскулінність як химера. Режим доступу : http://www.ji.lviv.ua/n 27texts/harrington.htm

3. Герман I. Експресивна тональність публіцистичного дискурсу тоталітарної журналістики (на матеріалі запорізької преси 20-40 років) ХХ ст. // Вісник Київського нац. ун-ту ім. Т. Г. Шевченка. 2004. - №12. - С. 35-38.

4. Гловінський М. 12 Польських Есеїв. Copuright by Ośrodek Badań nad Tradycją Antyczną Uniwersytet Warszawski / Міхал Гловінський - Warszawa, 2001. - 254 c.

5. Забужко О. Хроніки від Фортінбраса. Вибрана есеїстика / Оксана Забужко. - [3-є вид., доповн.]. - К. : Факт, 2006. - 352 с.

6. Масенко Л. Мова і політика / Лариса Масенко - К., 1999. - 100 с.

7. Потятиник Б. Медіа : ключі до розуміння. Серія : Медіакритика / Борис Потятиник. Львів : ПАІС, 2004. $-312 \mathrm{c}$.

8. Ставицька Л. Актуальні проблеми сучасної української гендерної лінгвістики. Режим доступу : http: //linguistics. kava.kiev.ua /seminar/2003/12/18/ sem01_01_6.html.

9. Федорова О. Сучасний український мас-медійний дискурс як предмет дослідження гендерної та когнітивної лінгвістики / О. Федорова // Рідна школа. - 2007. - № 6. - С. 67-69.

10. Яворська Г. Прескриптивна лінгвістика як дискурс : Мова, культура, влада / Г. М. Яворська - К. : ВІПОЛ, 2000. -288 с. 